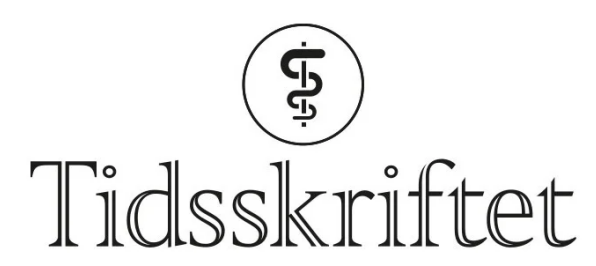

DEN NORSKE LEGEFORENING

\title{
Legeforeningenes forhold til tortur
}

\author{
KOMMENTAR
}

SVEIN AXEL WANNAG

Email: a.wannag@getmail.no

Borgenbråten 1078

1388 Borgen

\section{World Medical Association har vist manglende handlekraft ved spørsmål om tortur. Nye strukturelle endringer bør til for at organisasjonen kan fungere aktivt i slike saker.}

Kolleger som følger med i BMJ kan ha sett den løpende diskusjonen om de uklare forholdene rundt den israelske legeforening $(\underline{1}, \underline{2})$. Diskusjonen har dreid seg om foreningens leder dr. Yoram Blachars, hans forhold til tortur i praksis og World Medical Associations vegring mot å gjøre noe for å få avklart forholdet.

Jeg opplever verdensorganisasjonens manglende evne til å ta stilling til tortur i praksis som særdeles farlig og undergravende for organisasjonens troverdighet i torturspørsmål. Dette rammer også medlemsorganisasjonene, som vår egen legeforening.

Verdensorganisasjonens egen Tokyo-deklarasjon er klar og tydelig på at leger ikke skal delta i tortur, og at de både skal rapportere tilfeller av slik mishandling og protestere mot den. Men hva hjelper det når organisasjonen ikke reagerer når det meldes fra om at en legeforening muligens ser gjennom fingrene med at tortur foregår i praksis?

Dessverre foregår tortur, også med legers medvirkning, flere steder i verden $(\mathbf{1}, 3)$. World Medical Associations manglende evne til å reagere i disse sakene trenger ikke bare skyldes enkeltpersoners ønske om ikke å ta opp saker, det kan også ligge i organisasjonens struktur. Det er nemlig sekretariatet som håndterere sakene. Rådet, bestående av valgte medlemmer fra verdens legeforeninger, synes ikke å ha noen selvstendig rolle utover å behandle saker som sekretariatet $\emptyset$ nsker behandlet ved møtene to ganger i året. Dessuten er World Medical Association en organisasjon for verdens legeforeninger, og synes derfor å ha vansker med å forholde seg til henvendelser fra enkeltleger. Dette er kritisk når enkeltleger vil ta opp torturforhold som medlemmets legeforening ikke ønsker å få belyst.

Den britiske legeforening har nå foreslått at enkeltleger også skal kunne rapportere om torturforhold direkte til organisasjonen. World Medical Association kan da videresende slike meldinger til Rådet for menneskerettigheter i FN, som i mars 2009 vedtok en resolusjon om helsepersonells ansvar med henblikk på tortur (3,4). Resolusjonen er en legalt bindende norm med mulighet for rettsforfølgelse overfor stater, organisasjoner og 
individer. FN har også unders $\emptyset$ kelsesmulighet med personell som rapporterer til Rådet for menneskerettigheter $(3,4$.). Det er å håpe at dette kan være med på å gjøre WMA til det den bør være: en slagkraftig organisasjon i kampen mot tortur.

\section{Oppgitte interessekonflikter:}

Ingen

\section{LITTERATUR}

1. Kmietowicz Z. Doctors call for head of World Medical Association to quit as «matter of priority». BMJ 2009; 338: b2556.

2. Yudkin J. The Israeli Medical Association and doctor's complicity in torture. BMJ 2009; 339: b4078.

3. Polatin PB, Modvig J, Rytter T. Helping to stop doctors becoming complicit in torture. BMJ 2010; 340: 1973

4. UN Human Rights Council. Resolution on torture and other cruel, inhuman or degrading treatment or punishment: the role and responsibility of medical and other health personnel, 2009, A/HRC/10/L.32. http://blog.unwatch.org/wp-content/uploads/2009/03/march-hrc-torture.pdf(1.6. 2010).

Publisert: 1. juli 2010. Tidsskr Nor Legeforen. DOI:10.4045/tidsskr.10.0488

Manuskriptet ble mottatt 22.4. 2010 og godkjent 27.5. 2010. Medisinsk redaktør Anne Kveim Lie. (C) Tidsskrift for Den norske legeforening 2023. Lastet ned fra tidsskriftet.no 26. april 2023. 